\title{
PERANCANGAN APLIKASI MANAJEMEN PURCHASE ORDER ALUMUNIUM PADA PT. SUMBER MITRA KENCANA
}

\author{
Agung Prabowo', Dwi Dani Apriyani², Risma Nurul Auliya ${ }^{3}$ \\ Program Studi Informatika, Fakultas Teknik dan Ilmu Komputer, Universitas Indraprasta PGRI \\ Jalan Raya Tengah No 80, Kelurahan Gedong, Pasar Rebo, Jakarta Timur \\ agungprabowo996@gmail.com ${ }^{1}$, dwidani12@gmail.com ${ }^{2}$, rismauliya@gmail.com $^{3}$
}

\begin{abstract}
Abstrak
Dalam pembuatan aplikasi ini peneliti bertujuan untuk memudahkan pekerjaan Staff Purchasing dalam mengelola data barang dan pembuatan form order barang, sehingga pekerjaan yang berkaitan dengan pengandaan barang dapat terselesaikan secara lebih cepat, tepat dan efisien. Dalam penelitian ini metode penelitian yang digunakan menggunakan metode grounded research, yaitu metode penelitian yang mendasarkan diri kepada fakta di lapangan dan penggunaan analisis perbandingan, yang bertujuan untuk mengadakan generalisasi empiris, menerapkan konsep-konsep, membuktikan teori, dan mengembangkan teori, di mana pengumpulan data dan analisa data berjalan pada waktu yang bersamaan. Setelah peneliti menganalisa permasalahan yang ada, maka peneliti menyimpulkan bahwa di butuhkan sebuah aplikasi untuk menunjang kinerja dalam purchase order. Sehingga hasil dari penelitian ini adalah sebuah rancangan aplikasi purchase order (PO) dimana dalam membangun sistem ini memanfaatkan database MYSQL sebagai penyimpanan dan aplikasi desktop (Neatbeans) yang berbasis Java.
\end{abstract}

Kata Kunci: Aplikasi, Purchase order, Java, neabeans, MySQL

\begin{abstract}
In the manufacture of this application researchers aim to facilitate the work of Staff Purchasing in managing the data of goods and the creation of order form goods, so that the work related to the reproduction of goods can be resolved faster, precise and efficient. In this research method of research used using grounded research methods, namely the research method that bases itself on the fact in the field and the use of comparative analysis, which aims to conduct empirical generalization, Implementing concepts, proving theories, and developing theories, where data collection and data analysis run at the same time. Once the authors have analyzed the problem, the author concluded that it needed an application to support performance in the purchase order. So the result of this research is a draft purchase order (PO) application which in building this system utilizes the MYSQL database as a Java-based storage and desktop application (Neatbeans).
\end{abstract}

Keywords: Application, Purchase order, Java, neabeans, MySQL

\section{PENDAHULUAN}

Perkembangan teknologi dan informasi pada saat sekarang ini telah membuka peluang seluasluasnya kepada para pakar dan para pengambil keputusan. Perkembangan teknologi komputer telah mendorong terjadinya perubahan di berbagai ilmu, baik dalam kajian ataupun implementasi di lapangan. Peran teknologi komputer sangat diperlukan, baik oleh perusahaan kecil, menengah, maupun besar, mengingat kebutuhan akan peningkatan efisiensi dan efektivitas setiap kegiatan dalam perusahaan. Pekerjaan yang ada tidak dapat dilakukan secara cepat dan akurat tanpa ada dukungan teknologi tersebut.

PT. Sumber Mitra Kencana merupakan salah satu perusahaan yang sedang berkembang dan terus berupaya meningkatkan pelayanan kepada pelanggan.Kegiatan usahanya, antara lain menjual kusen dan kaca yang telah siap di aplikasikan. Produk usaha yang ditawarkan PT. Sumber Mitra Kencana, yaitu berupa window wall, curtain wall, kaca framless dan foldingdoor. Bagian marketing perusahaan, purchaseorder, dan bagian lapangan perlu untuk demi menjalin kerjasama yang baik demi kemajuan perusahaan. 
Di dalam era persaingan industri yang sangat ketat, perusahaan berusaha meningkatkan kualitasnya, salah satunya yaitu dengan meningkatkan sistem yang ada dalam perusahaan tersebut. Ada banyak sistem yang terdapat pada setiap perusahaan, salah satunya adalah sistem pembelian (purchase) yang digunakan untuk mencatat semua pembelian barang dagang dalam satu periode (Soemarso, 2012). Pada perusahaan PT Sumber Mitra Kencana sistem pembelian dilakukan oleh bagian pembelian. Pertama, bagian produksi akan membuat form pengajuan pengadaan matrial yang akan diberikan pada bagian pembelian, yang kemudian akan diberikan kepada direktur keuangan. Jika bagian direktur keuangan memberikan persetujuan pembelian barang tersebut maka bagian pembelian akan melakukan penawaran kepada pemasok,tetapi sebelum melakukan penawaran,bagian pembelian sudah melakukan penyeleksian pemasok. Bagian pembelian akan mengambil harga barang yang paling murah dari pemasok. Setelah perusahaan merasa cocok dengan harga yang diberikan oleh pemasok, bagian pembelian akan membuat Purchase Order (PO), yang kemudian akan dikirim kepada pemasok via email. Setelah barang datang, barang beserta surat jalan akan diterima oleh bagian gudang.

Sayangnya, dalam proses purchase order (PO) dan pencatatan barang datang yang dilakukan masihsecara manual, yaitu dengan menggunakan lembaran-lembaran kertas yang berisi form. Hal ini menyebabkan bagianpurchase order sering mengalami salah input harga ataupun item alumunium pada saat pembuatan formpurchase order (PO), serta kehilangan berkas ataupun data yang telah di-print out. Oleh karena itu dibutuhkan suatu aplikasi yang dapat membantu bagian pembelian dalam membuat purchase order (PO), serta merekap data barang yang diterima dari pemasok untuk membuat laporan pembelian.

Didalam penelitian ini peneliti bertujuan untuk merancang dan membangun aplikasi purchase order alumunium bebasis Java untuk meminimalisir kesalahan input data yang terjadi pada PT Sumber Mitra Kencana, dengan mengidentifikasi dan mendata barang alumunium, sehingga dapat memberikan data yang akurat saat pembuatan aplikasi form purchase order. Perancangan sendiri adalah proses pengembangan spesifikasi baru berdasarkan hasil analisa sistem. Dengan kata lain, perancangan adalah suatu konsep yang dituangkan secara terinci dan dibuat untuk satu kesatuan yang utuh dan berfungsi sebagaimana mestinya (Subhan 2012). Hasil dari perancangan tersebut akan berupa aplikasi order barang alumunium yang dapat meminimalisir kesalahan input data harga barang dan item barang yang dilakukan user pada saat pembuatan form purchase order dan melakukan monitoring kedatangan barang. Aplikasi sendiri merupakan sistem yang dirancang dan disusun sedemikian rupa untuk menghasilkan informasi yang terpadu dengan menggunakan sarana computer sebagai sarana penunjangnya(Pramana 2012). Manfaat yang diharapkan oleh peneliti yakni untuk memperlancar dan mempermudah pengolahan data purchase order barang alumunium khususnya dalam penginputan, penyimpanan, dan pembuatan laporan data harga barang serta menambah wawasan bagi peneliti dalam merancang aplikasi purchase order alumunium yang dilakukan oleh PT.Sumber Mitra Kencana.

\section{PENELITIAN RELEVAN}

Wira Indra Wijaya, Universitas Indraprasta PGRI tahun 2018 dengan judul "Perancangan Aplikasi Purchase Order padaPT.Dwimitra Elektrindo Jakarta Selatan". Dari hasil penelitian dinyatakan aplikasi purchase order dirancang untuk memenuhi kebutuhan PT.Dwimitra Elektrindo sehingga proses pembelian menjadi lebih mudah, efisien, dan cepat dalam menyelesaikan pekerjaan dan meminimalisir kesalahan akibat proses manual (Wijaya 2018).

Eka Maulana Weihardi, Universitas Indraprasta PGRI tahun 2018 dengan judul "Rancang Bangun Sistem Permintaan Barang (Purchase Order) PT. Mgm Bosco". Dari hasil penelitian yang di lakukan peneliti merancang sebuah aplikasi bangun sistem permintaan barang (purchase order) PT. Mgm Bosco, dapat mengurangi terjadinya kesalahan dalam pencarian data barang dan data pembelian barang, serta lebih efektif, cepat dan up to date dalam pengolahan datanya (Weihardi 2018). 


\section{METODE PENELITIAN \\ Rancangan Sistem}

Rancangan sistem bertujuan untuk merancang sistem yang akan dibuat agar dapat diimplementasikan dengan kebutuhan pengguna yaitu PT. Sumber Mitra Kencana.

\section{Teknik Pengumpulan Data}

Penelitian ini menggunakan metode grounded reseach adalah suatu metode penelitian yang mendasarkan diri kepada fakta dan penggunaan analisis perbandingan, yang bertujuan untuk mengadakan generalisasi empiris, menerapkan konsep-konsep, membuktikan teori, dan mengembangkan teori, di mana pengumpulan data dan analisa data berjalan pada waktu yang bersamaan (Nazir, 2013). Dalam grounded research, data merupakan sumber teori, dan teori disebut grounded karena teori tersebut berdasarkan data. Data yang diperoleh dibandingkan melalui kategori-kategori.

Tujuan dari grounded research yaitu mengadakan generalisasi empiris, menetapkan konsep, membuktikan teori, mengembangkan teori, dan menspesifikasikan konsep (Barnabas, 2012). Perdandingan tersebut dapat menjelaskan unsur-unsur baru dari kasus yang sedang dipelajari.Dengan metode ini, peneliti melakukan pengumpulan data dan analis data dalam waktu yang bersamaan, sehingga perancangan sistem ujian yang dibuat berdasarkan fakta yang ada di lapangan. Metode pengumpulan data yang dilakukan oleh peneliti untuk mendapatkan data-data serta informasi untuk mendukung penyempurnaan hasil dari penelitian ini yaitu dengan studi lapangan, wawancara, observasi, dan studi keperpustakaan.

\section{Langkah-Langkah Pengembangan Sistem}

Metode pengembangan sistem yang digunakan peneliti adalah Waterfall, dengan tahapan tahapan seperti System engineering yaitu pengumpulan data dan penetapan kebutuhan semua elemen sistem, Requirements analysis yaitu melakukan analisis terhadap permasalahan yang dihadapi dan menetapkan kebutuhan perangkat lunak, Design yaitu menetapkan domain informasi untuk perangkat lunak, Coding yaitu mengimplementasikan hasil desain ke dalam bahasa yang dimengerti oleh mesin computer, Testing yaitu kegiatan untuk melakukan pengetesan program yang sudah dibuat, Maintenance yaitu melakukan perawatan pada perangkat lunak yang sudah selesai supaya dapat berjalan dengan lancar, dan berikut alurnya sesuai gambar:

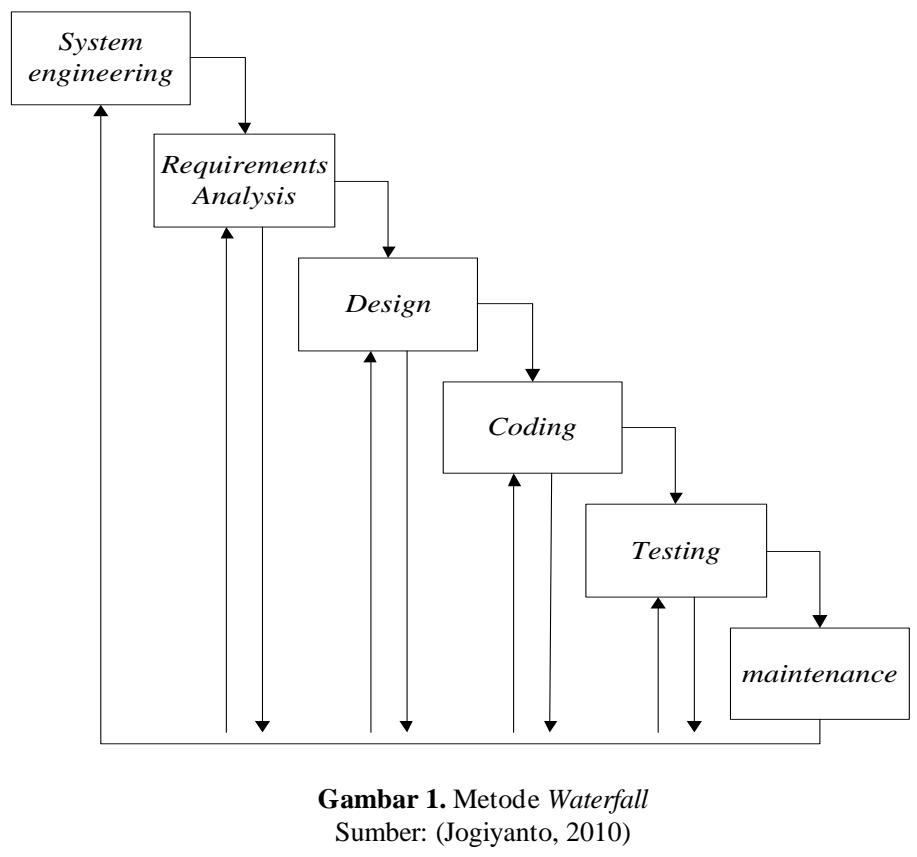




\section{HASIL DAN PEMBAHASAN}

Pada penelitian ini peneliti menjelaskan permasalahan yang sedang dihadapi oleh bagian purchasing yaitu proses kegiatan sistem berjalan yang saat ini ditetapkan pada PT.Sumber Mitra Kencana belum menggunakan sebuah aplikasi pendukung yang khusus. Permintaan, pembelian, pendataan, pencarian data dan laporan barang masih dilakukan secara manual yang memungkinkan terjadinya kesalah dalam input ataupun pencarian data.

Dan dalam penyelesaian permasalahan yang dihadapi oleh bagian purchasing, peneliti membangun sebuah aplikasi purchase order alumunium bebasis Java untuk meminimalisir kesalahan input data yang terjadi pada PT Sumber Mitra Kencana. Aturan sistem yang diusulkan, ada beberapa prosedur yang harus dijalankan untuk memenuhi setiap kegiatan, Adapun prosedurnya yaitu bila ada permintaan barang batangan alumunium dari bagian estimate, purchasing akan mendata permintaan, selanjutnya data permintaan barang akan di olah sebagai informasi estimate, dan purchasing, hasil data yang telah diolah, disimpan di rak penyimpanan data pada bagian purchasing. Selanjutnya Purchasing memeriksa permintaan barang dari estimate, untuk selanjutnya dilakukan pengadaan barang dengan pembuatan purchase order (PO) yang akan di berikan ke suplier. Setelah barang datang purchasing akan melakukan pengecekan barang secara fisisk, dan selanjutnya diserahkan ke bagian gudang untuk disimpan sementara sebelum barang diinfokan ke estimate untuk di kirim ke customer. Purchasing melakukan pengecekan kedatangan barang melalui surat jalan. Setelah surat jalan sesuai dengan pesanan, bagian purchasing melakukan pengesahan surat jalan barang dengan menandatangani surat jalan yang dibawa oleh pengirim sebagai tanda bukti pengiriman telah berjalan dengan baik.

Berikut ini merupakan penggambaran tentang sistem yang diusulkan pada perancangan aplikasi purchase order secara keseluruhan dalam bentuk diagram konteks.

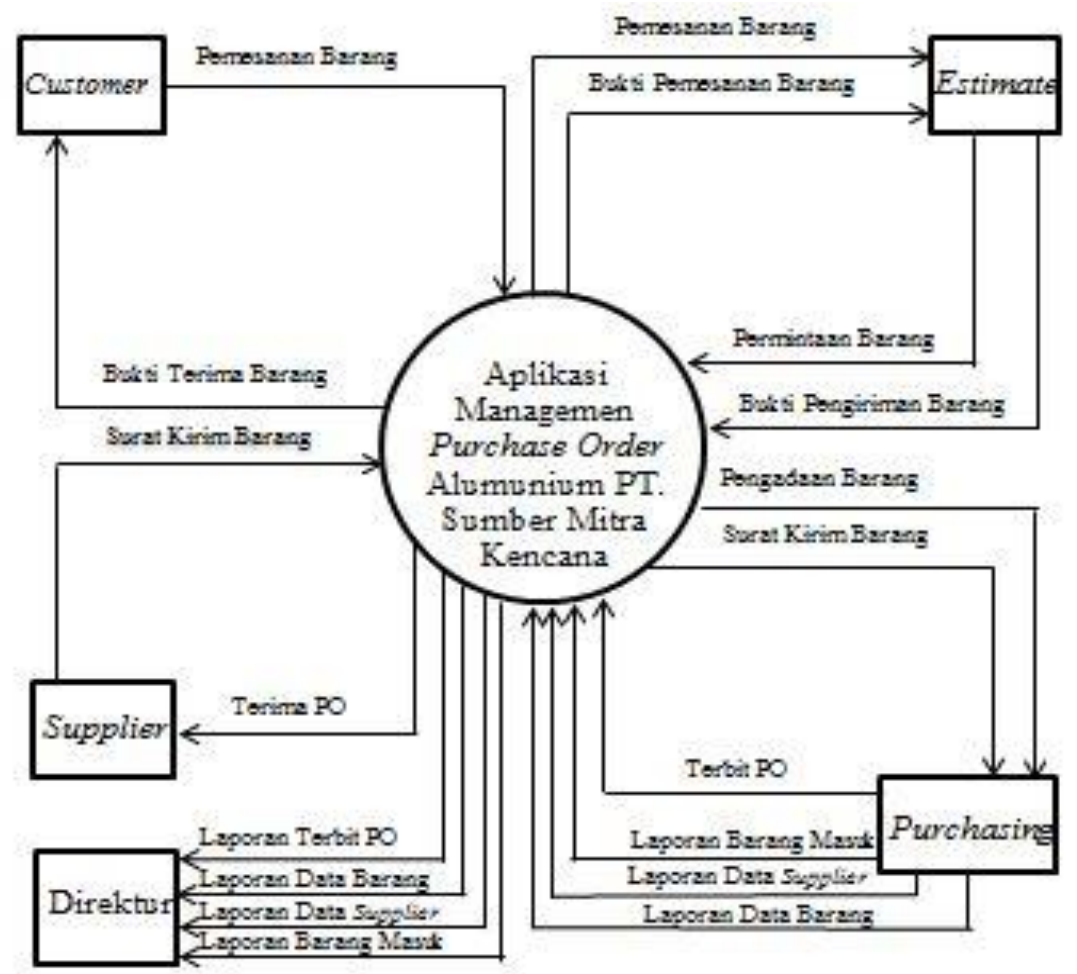

Gambar 2. Diagram Konteks Sistem Purchase Order 


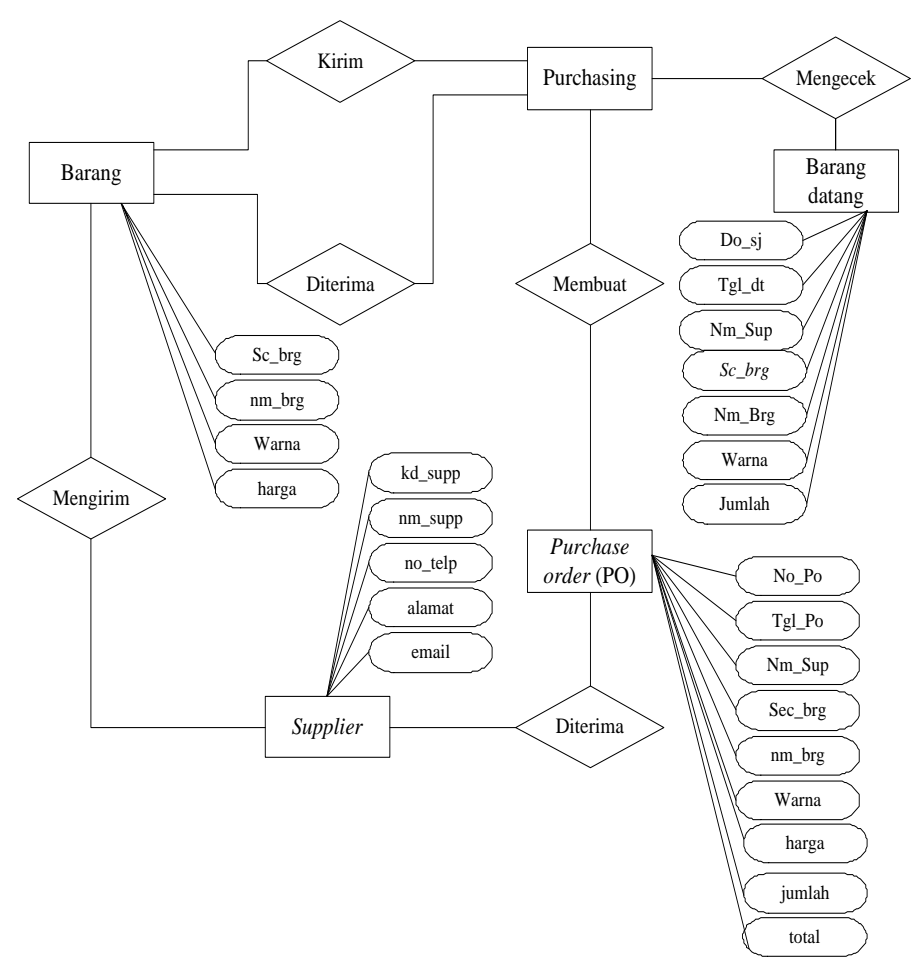

Gambar 3. ERD (Entity Relationship Diagram)

Selanjutnya peneliti membuat aplikasi dengan menggunakan java berbasis dekstop dan database mysql. Berikut ini adalah rancangan dan tampilan dari Aplikasi manajemen purchase order alumunium pada PT.Sumber Mitra Kencana berbasis java:

\section{Tampilan Aplikasi}

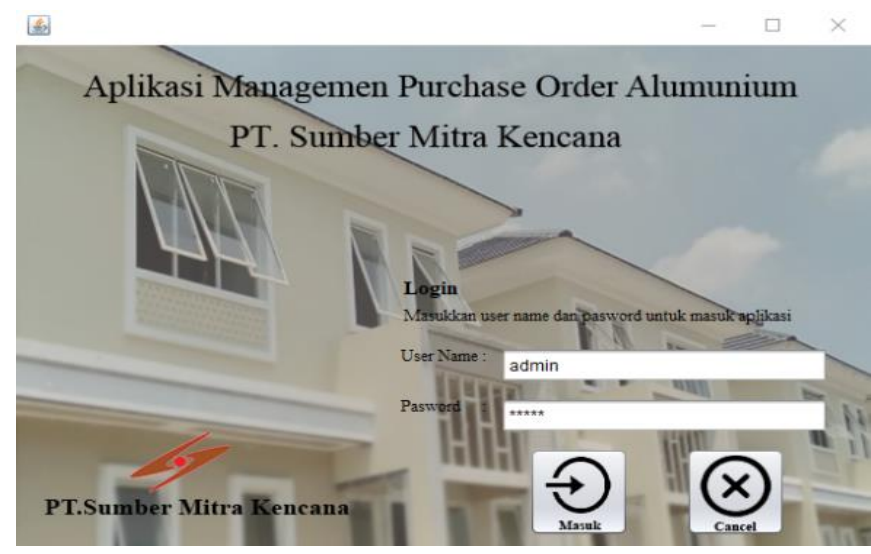

Gambar 3. Tampilan Menu Login

Tampilan menu login ini muncul di awal saat pengoperasian program aplikasi sistem inventory barang untuk diisi oleh admin.Admin memasukkan username dan password yang sesuai dengan hak kases supaya bisa mengoperasikan sistem. Jika username dan password sesuai, maka akan masuk ketampilan menu utama. 


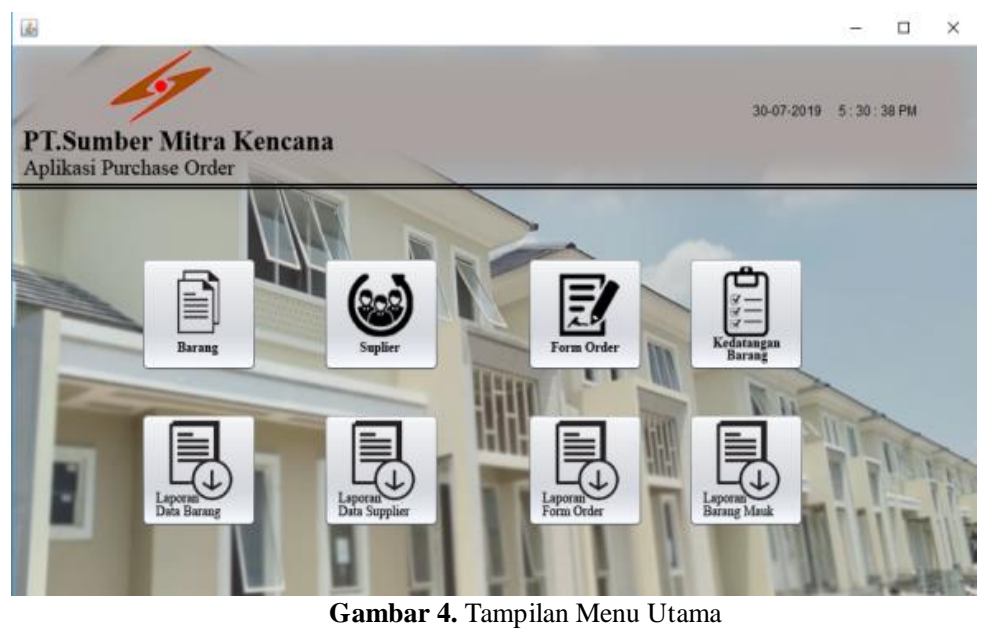

Tampilan menu utama Rancangan Aplikasi Manajemen Purchase Order Alumunium Berbasis Java pada PT.Sumber Mitra Kencana, pada layar utama tersedia pilihan action data barang, data supplier, form order, dan kedatangan barang.

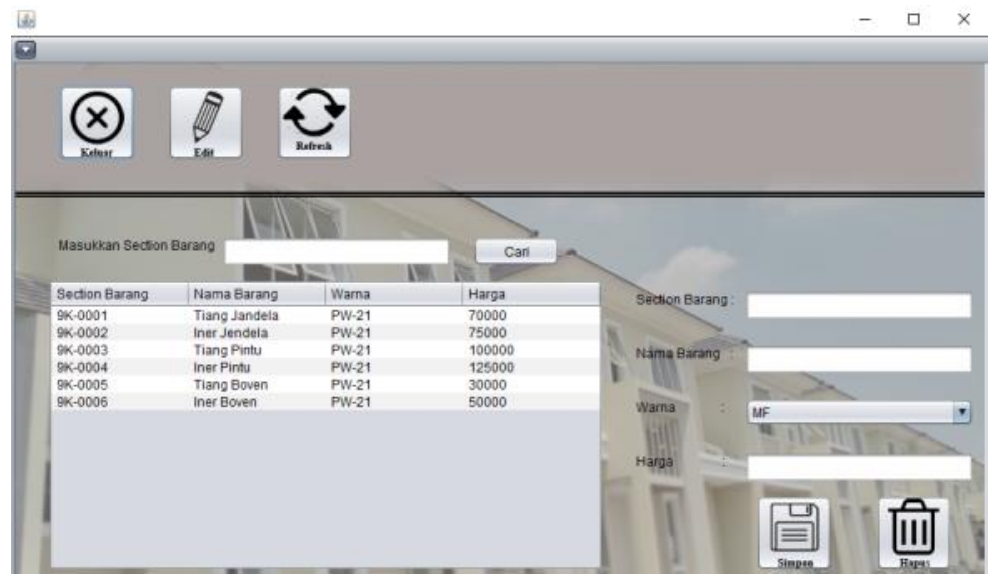

Gambar 5. Tampilan Data Barang

Purchsing dapat melakukan penambahan data barang, mengubah data barang, menghapus data barang dan mencari data barang. Untuk menambahkan data barang maka purchsing harus mengisi form kode barang, nama barang, jumlah dan harga lalu kemudian memilih button simpan untuk menyimpan.

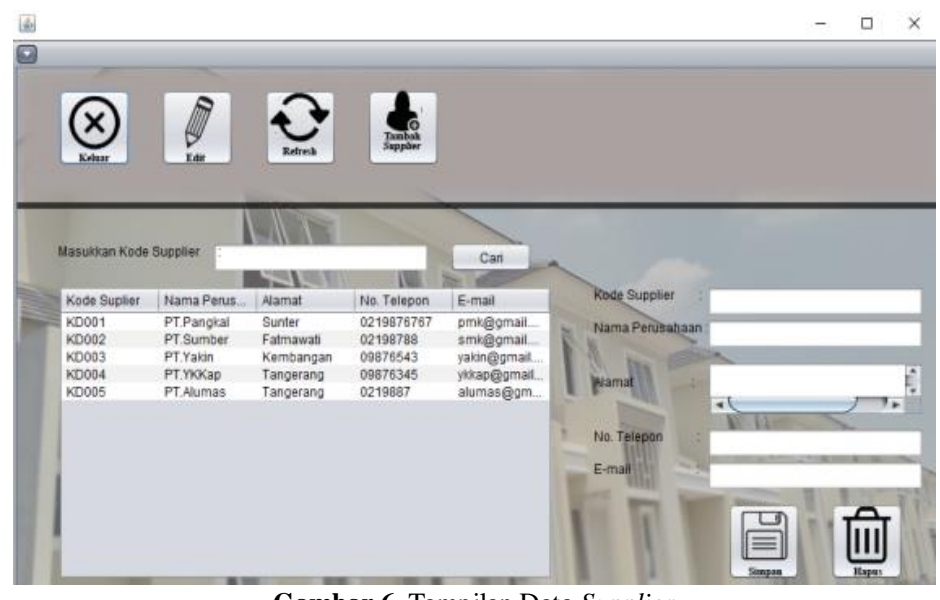

Gambar 6. Tampilan Data Supplier

Purchasing dapat melakukan penambahan data supplier, mengubah data supplier, menghapus data supplier dan mencari data supplier. Untuk menambahkan data supplier maka admin harus mengisi 
form kode supplier, nama supplier, alamat, nomor telepon dan e-mail lalu kemudian memilih button simpan untuk menyimpan.

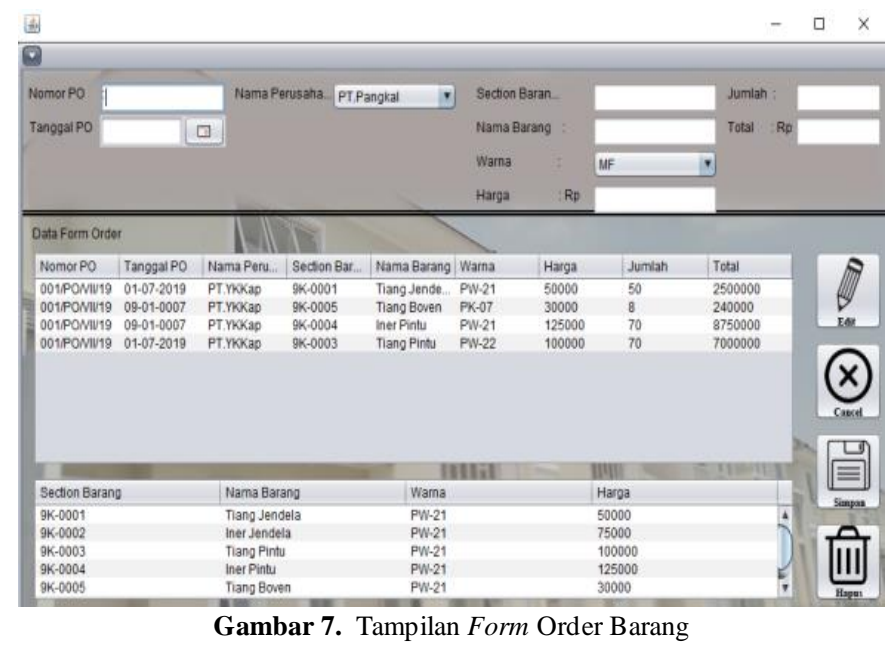

Purchasing dapat melakukan pembuatan data from order barang, mengubah data barang yang akan di order, menghapus data barang yang akan diorder. Untuk menambahkan data barang yang akan diorder maka purchsing harus mengisi form order barang, nomor purchase order (PO), tanggal purchase order (PO), nama supplier, dan data barang. Lalu kemudian memilih button simpan untuk menyimpan.

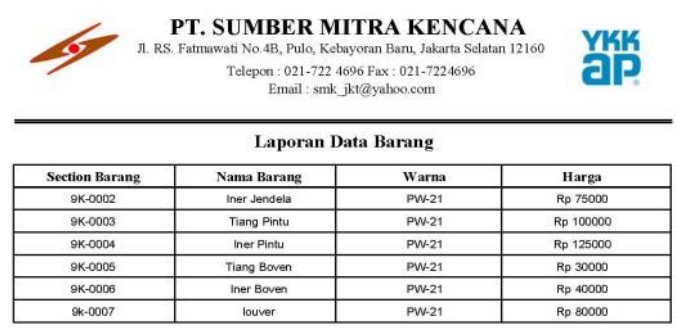

Pada tampilan form laporan data barang ini berisi data-data yang ada pada tabel data barang. Laporan ini muncul ketika purchasing mengklik button print pada menu laporan data barang. 

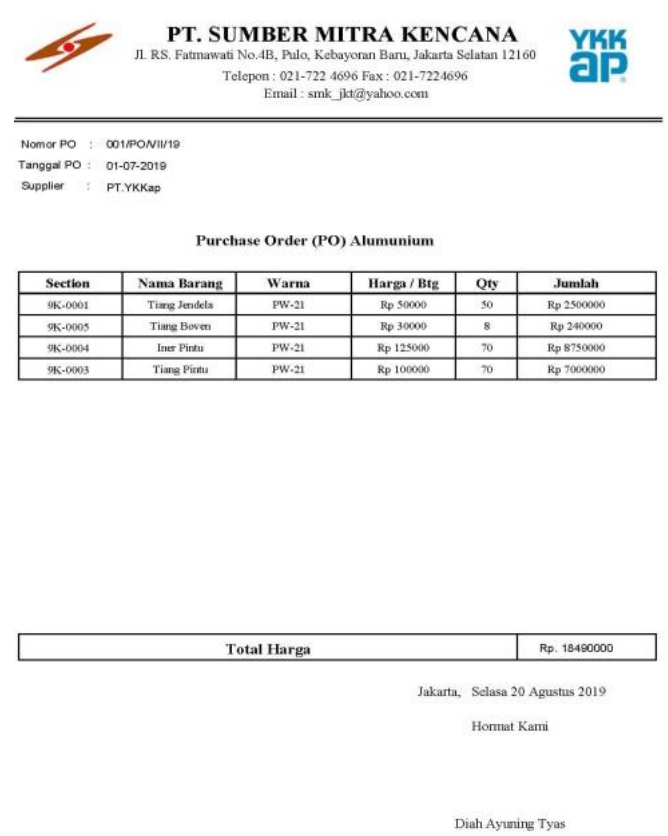

Gambar 9. Tampilan Form Order Barang

Pada tampilan form order barang ini berisi data-data yang ada pada tabel data form order barang. Laporan ini muncul ketika purchasing mengklik button print pada menu laporan data form order barang.

\section{SIMPULAN}

Dengan dibuatnya aplikasi manajemen purchase order alumunium pada PT. Sumber Mitra Kencana semua kegiatan yang berhubungan dengan pengolahan data purchase order alumunium dapat berjalan dengan baik dan lancar. Pada aplikasi ini, bagian purchasing dapat menangani pekerjaan pembuatan formPurchase Order (PO) dan update data pembelian dengan cepat dan akurat. Dan dengan adanya aplikasi ini diharapkan akan mempermudah kegiatan atau aktivasi pekerjaan yang memerlukan kecepatan dan ketetapan informasi. Dengan demikian, beberapa kesimpulan yang diperoleh dari penelitian ini antara lain, kesalahan input yang sering terjadi pada pembuatan formpurchase order (PO) dapat diminimalisir, data barang yang digunakan dalam pembuatan formpurchase order ( $\mathrm{PO}$ ) alumunium menjadi lebih ter-update, proses input dan output laporan serta monitoring kedatangan barang menjadi lebih terkonsep dan terperinci.

\section{DAFTAR PUSTAKA}

Barnabas, B. 2012. "Metode Penelitian Grounded Research."

https://www.academia.edu/8363807/Grounded_Research_Grounded_Theory_Metode_Penelitian_Grounded_oleh _Baren_Barnabas?auto=download.

Eka Maulana Weihardi. 2018. Rancang Bangun Sistem Permintaan Barang (Purchase Order) PT. Mgm Bosco. Jakarta.

Nazir, Moh. 2013. Metode Penelitian. Bogor: Ghalia Indonesia.

Pramana, Hengky. 2012. Aplikasi InventoryBerbasis Access 2003. Jakarta: PT. Elex Media Komputindo.

Soemarso. 2012. Akutansi Suatu Pengantar. Jakarta: Salemba.

Subhan, Mohamad. 2012. Analisa Perancangan Sistem. Jakarta: Lentera Ilmu Cendikia.

Wijaya, Wira Indra. 2018. Perancangan Aplikasi Purchase Order Pada PT. Dwimitra Elektrindo Jakarta Selatan. Jakarta. 